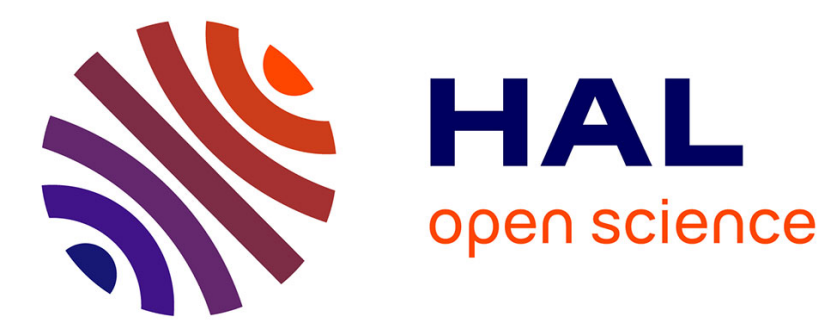

\title{
Urban Media Trends for Enabling Citizen Participation in Urban Planning: Old Wine in New Barrels?
}

\author{
Bert P. Groot, Robin Effing, Mettina Veenstra
}

\section{To cite this version:}

Bert P. Groot, Robin Effing, Mettina Veenstra. Urban Media Trends for Enabling Citizen Participation in Urban Planning: Old Wine in New Barrels?. 10th International Conference on Electronic Participation (ePart), Sep 2018, Krems, Austria. pp.51-63, 10.1007/978-3-319-98578-7_5 . hal01985604

\section{HAL Id: hal-01985604 https://hal.inria.fr/hal-01985604}

Submitted on 18 Jan 2019

HAL is a multi-disciplinary open access archive for the deposit and dissemination of scientific research documents, whether they are published or not. The documents may come from teaching and research institutions in France or abroad, or from public or private research centers.
L'archive ouverte pluridisciplinaire HAL, est destinée au dépôt et à la diffusion de documents scientifiques de niveau recherche, publiés ou non, émanant des établissements d'enseignement et de recherche français ou étrangers, des laboratoires publics ou privés. 


\title{
Urban Media Trends for Enabling Citizen Participation in Urban Planning: Old Wine in New Barrels?
}

\author{
Bert P. Groot ${ }^{[1]}$ Robin Effing ${ }^{[12]}$ Mettina J.A. Veenstra ${ }^{[1]}$ \\ ${ }^{1}$ Saxion University of Applied Sciences, P.O. Box 70.000, 7500 KB Enschede, The Nether- \\ lands \\ ${ }^{2}$ University of Twente, P.O. Box 217, 7500 AE, Enschede, The Netherlands \\ b.p.groot@saxion.nl
}

\begin{abstract}
In recent years, a plethora of new possibilities for interactive urban planning emerged, fuelled by the rise of smart cities. This paper studies the potential of urban media for reshaping the role of citizens in urban planning. Both the historical role that citizens have played in the development of neighbourhoods and the process of urban planning are presented from a literature review. Furthermore, present visions on urban planning and citizen participation in smart cities are reviewed. Lessons learned from this literature study, are confronted with six main trends in urban media from expert interviews. As a result, we deliver an overview that helps urban planners in neighbourhoods in order to profit from advantages of urban media while avoiding their risks. We found that the development of urban media could have both positive and negative effects with regard to citizen participation in urban planning in neighbourhoods.
\end{abstract}

Keywords: Smart city, Urban Media, Citizen Participation, Area Development.

\section{Introduction}

Citizens have become smarter due to their access to the internet, social media and other digital media, in particular in cities. Both the rise of the smartphone and mobile internet access have reshaped city life. Ever more cities develop specific strategies for bearing the fruit of smart and digital consumer technologies in a wide variety of policy fields and in spatial development [1]. Well known cities, often mentioned in literature as smart cities, are cities such as Barcelona, Amsterdam, Songdo, London and Masdar [2, 3].

Parallel with the increase of the possibilities for cities and local governments to become smart cities the possibilities for its inhabitants to become a smart citizen keep increasing as well [4-7]. The online toolkit available to smart citizens, can radically reshape the way they engage in the development of their own living environments. Urban media interactions are a key part of such an online toolkit. Urban media is a term that describes a wide variety of 'new' media that influence the use of public space. Examples of such media are mobile smartphone apps, social media, virtual reality and augmented reality $[2,8]$. 
In today's networked society, as introduced by Castells [9], citizens tend to gain a more central role in urban planning [8]. The combination of these developments raise the question what the impact of urban media is on urban planning practices. Therefore, the main question of this article is; What is the added value of urban media trends for citizen participation with regard to area development within existing neighbourhoods? The main aim of this research is to gain insight in the opportunities and risks of the use of urban media, within the process of area development in neighbourhoods. More specifically, on the role of citizen participation. The research method consists of both literature review and qualitative research with experts. First, in the beginning of 2017 , we performed a literature review concerning the involvement of citizen in area development. Insights in area development in neighbourhoods were derived from experts in policy making and area development. Since Hajer warned that "the smart city discourse is notoriously weak on historical awareness" [10], we have chosen to start the literature research with insights gained in early twentieth century. Also, contemporary literature was included with topics such as smart cities and area development. The second part of the study was based on qualitative expert interviews. Eight experts were interviewed regarding trends and developments with respect to urban media. These interviews were conducted in a face-to-face setting and used a semi-structured list of questions. Experts were selected from fields of expertise including area development in smart cities, participatory smart city developments and ICT. Expert interviews led to the definition of six relevant trends in urban media. Those trends were then confronted with the characteristics of area development.

The remainder of this article is structured as follows. In section 2 we introduce a theoretical background. In section 3 we will introduce the trends in urban media. In section 4 we show an analysis of the findings. The final section is discussion.

\section{Theoretical background}

The key concepts of this research are urban media, citizen participation and area development. We are aware of the vast amount of literature that covers the opportunities and pitfalls of e-participation and smart cities. We did not strive to provide a comprehensive overview of that body of literature. We focus completely on the new opportunities of Urban Media for area development in neighbourhoods. The term urban media is relatively new and has a relatively small base in literature. In 2018, only 81 peer-reviewed articles can be retrieved from Scopus mentioning this term in the abstract, keywords or title.

\subsection{Participation in area development}

Throughout the history of mankind, the quality of life in cities has been a matter of concern for city planners. Also, citizens influenced their own living areas. In early models, city planning was a heavily rationalized process, developed in a top-down manner. Urban designers presented blueprints of housing areas that needed to create a living area for the rapidly growing cities. The role of citizens in the development of these 
plans was marginalized [11]. Models that had quality of life and diversity for inhabitants in mind started in late 19th century when industrialization created very bad living circumstances in rapidly growing cities. Ebenezer Howard proposed his famous model of Garden Cities in 1898. A model that he created as a reaction on the poor living conditions in English cities, such as London. His solution was to create a network of satellite cities with a maximum of 32000 inhabitants, surrounded by large green areas [8]. One could say that he would almost abolish cities, in favor of good living conditions for inhabitants. Not much later Le Corbusier proposed an opposite approach to the problem of dense and polluted cities of that time. His plans for 'La ville radieuse' and 'La ville contemporaire' proposed the development of megacities with millions living in it but build up as large buildings surrounded by massive green areas, thereby creating a livable space for inhabitants. The problem both plans tried to solve was the same: to create better living conditions for the people in the cities [12]. The CIAM-congresses in Europe or the mass development of New York under supervision of city planner Robert Moses, generated urban development plans regarding livable neighbourhoods for citizens. All of them doing so without actual participation of citizens. Much of the large-scale expansions of cities, pre and post-world war two, where developed in that way [13].

In the second half of the twentieth century a shift took place in the views on area development. Most prominent under the influence of Jane Jacobs, after she wrote her famous book "The Life and Death of Great American Cities" in 1961. [14]. This created a more central role for citizens in the process of city planning. Her plea for more actual involvement of citizens within the process of city making gained much acclaim and follow up. In 1965, Davidoff presented his influencing model of Advocacy planning [15]. A planning model that plead for more equality in urban planning. The model emphasizes the importance including the interests of several target groups living in urban areas [15]. Jacobs and Davidoff stressed that a broad representation of the public and participating in creating livable living conditions are crucial factors.

Already in 1969, Sherry Arnstein was the first to introduce a participation ladder theory to describe various levels of influence citizen can have in a policy making process [16]. Her model was widely accepted and evolved into several adaptations of the model including e-participation ladders. However, there is not much consensus within those different ladders [17]. An important lesson was that citizens could take different roles in the participation process [18].

\subsection{New relations between citizen and government}

In the last decade, another shift in the planning discourse can be acknowledged towards citizen leadership in urban development, particularly in neighbourhoods. Terms such as co-creation or grassroots initiatives describe this process [19]. In a new planning philosophy called radical incrementalism, a shift takes place in de the roles of government and civil society [20]. Unlike models of the past, governments do not propose blueprints of policy, but set wider, larger scale goals. Every project, initiative or experiment that seems beneficial for achieving these goals, is approached in a cooperative manner. Experiments that succeed, could be learned from and if scalable, implemented 
on a larger scale. The dynamics of contemporary society functions as a catalyst for new ideas, projects and initiatives. Through process of trial and error, society learns what could be implemented successfully and what not. The model is based in the principles of incremental planning [21]. The model of radical incrementalism teaches us that a shift in ownership for policymaking and area development is necessary. Therefore, three principles regarding new relations between government and civil society are [20]:

1. Acknowledge the paradigm of the energetic society, for both finding solutions as in approach to policy challenges;

2. Attach to the experiences of the citizen;

3. Consider the societal dynamics as a catalyst for solutions, not for problems.

In this new relations and field of influence it is important for local governments to be clear in the role they take in different projects with regard to area development.

\subsection{The smart citizen}

With the rise of smart cities and its possibilities, the position of citizens change [1]. Together with the previously described changing discourse in urban planning and area development, the role citizens can play in the development of their own neighbourhoods can be redefined. As Castells described, internet and connectivity transformed our society into a network society [9]. The network society gives increasing opportunities and freedom of choice in groups to which we can bind ourselves and to which we feel connected. A process described by Wellman as networked individualism [22]. The individual citizen functions as a switchboard between the different networks. This creates a very strong, horizontally oriented organizational structure that could be used for citizen to organize themselves, improve experiments, exchange ideas and learn [23].

This provides the citizen with instruments creating possibilities that makes bottomup area development possible. A process Townsend describes as a do-it-yourself-city [24]. The do-it-yourself-city is strengthened by the strong organizational structure of networked individualism. Townsend defines the do-it-yourself-city as 'a city that is not centrally operated, but a city that is created, operated and improved upon by all'. This shows that the impact of networked individualism, also affects the role citizens play in area development in their own neighbourhoods.

In the Datapolis [25] approach, city's government is seen as a central body, that makes decisions based on the gathering of urban data. The Centro de Operacoes Rio in Rio de Janeiro is a remarkable example of this type of governing. The role of citizen is marginalized. The opposite of this approach is a city that is not controlled from the cockpit, but commences out of a whole of uncoordinated activities, like a swarm [25]. This way of governing fits perfectly in the described shift in roles for citizen participation, and the shift towards networked individualism. Many authors now take an integrated perspective on smart cities instead of merely pushing technology. Caragliu, Del Bo and Nijkamp [26] state that a city is smart when: "investments in human and social capital and traditional (transport) and modern (ICT) communication infrastructure fuel sustainable economic growth and a high quality of life, with a wise management of natural resources, through participatory governance." As Neirotti et al. made clear, a 
smart city can only be really smart when the city is capable of addressing real-life challenges and when it is able to bear the fruit of the social capital of the people involved in that city [27]. The involvement of smart citizens is essential. Smart citizens play a crucial role in smart cities by their participation in smart governance of local areas where they live or work [28].

\subsection{Smart citizen participation in neighbourhood area development}

After the review of literature regarding the role of citizens in urban development in neighbourhoods, and analyzing the outcomes, we defined seven crucial aspects regarding the role of citizens in area development. These are:

1. Sufficient possibilities for citizens to participate $[14,20]$

2. Clear definition of the level of participation [4, 16, 18, 29]

3 . Enough diversity in the group of participants $[14,15]$

4. Enough influence from minorities in a neighbourhood [14, 15]

5. A broader government goal as a compass for area development [20]

6. Enough institutional freedom to experiment [20, 21]

7. Using the dynamics in society as a catalyst for participation [20]

\section{Results}

Urban media can influence the experience, use and value of physical places in a city [8]. Smartphones enable us to bridge both time and place. Apps are contributing to new forms of experience within neighbourhoods and could contribute to social cohesion (e.g. bridging and bonding social capital [30]). In today's society, the poster on a façade is replaced by the interface of a smartphone [33]. Urban media are developed into more personal, time and place independent, and more responsive forms of media. We conducted semi-structured interviews with eight experts for identifying trends in urban media. We aimed to explore the influence of urban media trends on area development. Since the experts were regarded as authorities within the field of urban development or urban media, we decided to list all key trends in Table 1.

Table 1. Trends in Urban Media as indicated by field experts

\begin{tabular}{ccccccc}
\hline Interviewee \# & $\begin{array}{l}\text { Plat- } \\
\text { form so- } \\
\text { ciety }\end{array}$ & $\begin{array}{l}\text { User gen- } \\
\text { erated } \\
\text { content }\end{array}$ & $\begin{array}{l}\text { Use of im- } \\
\text { age } \\
\text { video }\end{array}$ & $\begin{array}{l}\text { Serious } \\
\text { and } \\
\text { gaming }\end{array}$ & $\begin{array}{l}\text { VR } \\
\text { \& } \\
\text { AR }\end{array}$ & $\begin{array}{l}\text { Tech actors } \\
\text { in urban field }\end{array}$ \\
\hline Interviewee 1 & $\mathrm{X}$ & & & & & \\
Interviewee 2 & $\mathrm{X}$ & $\mathrm{X}$ & $\mathrm{X}$ & & \\
Interviewee 3 & $\mathrm{X}$ & $\mathrm{X}$ & $\mathrm{X}$ & & \\
Interviewee 4 & $\mathrm{X}$ & $\mathrm{X}$ & $\mathrm{X}$ & $\mathrm{X}$ & \\
Interviewee 5 & $\mathrm{X}$ & $\mathrm{X}$ & $\mathrm{X}$ & & \\
Interviewee 6 & $\mathrm{X}$ & $\mathrm{X}$ & $\mathrm{X}$ & & & $\mathrm{X}$ \\
Interviewee 7 & $\mathrm{X}$ & & & & \\
Interviewee 8 & & &
\end{tabular}




\subsection{Trend 1. Networked individuals in a platform society}

According to many of our interviewees, the networked society is shifting towards a platform society [33-35]. The process of networked individualism makes citizen more and more footloose. A citizen does not necessarily bind himself to his neighbourhood. The perception of a place can commence even if one doesn't actually know a place, or even has been to a place. Through the omnipresence of media, a form of hybrid space is developed. The use of a smartphone as a territory device magnifies this effect. This even makes the definition of new groups of people possible [8]. Most of the urban media on smartphones operate on a (online) platform. Van Dijck et al. [33] described this process as a shift towards a platform society. Helmond [35] speaks of "platformification', in which societal, social, and economic life for major parts runs through platforms. Four main companies (Google, Amazon, Facebook and Apple) dominate the platform landscape. A downside of such platforms is the risk of creating so called filter bubbles [5], caused by recommender algorithms.

\subsection{Trend 2. User generated content}

Users generate all kinds of posts, textual or audio-visual, and share them via platforms such as YouTube and Instagram [36, 37]. User generated content is the fuel for smart cities. According to Kaplan and Haenlein [36], user generated content needs to fulfil three basic requirements in order to be considered as such:

1. It needs to be published either on a publicly accessible website or on a social networking site accessible to a selected group of people;

2. It needs to show a certain amount of creative effort;

3. It needs to have been created outside of professional routines and practices.

This enables the growth of urban media, the mining of citizen generated data, partly as a result of urban media use, is growing. User-generated content can be used as possibilities for citizens to influence their own living areas. It can also be used for knowledge production in political participation [37]. Furthermore, extensive analysis of user generated content, as described in the cockpit metaphor, makes policy-making possible whilst taking the ideas and interests of a large and diverse population into account that lives in a neighbourhood. When data is collected on a variety of topics and among a relevant group of people, a form of indirect citizen participation could be achieved.

\subsection{Trend 3. The growing importance of image and video}

Visual social media channels such as YouTube, Instagram and Snapchat are getting more popular [38]. What those channels have in common is their emphasis on pictures and video as their most important way of communication. Politicians, for example, discover its visual possibilities to more easily reach voters and show their faces, increasing social presence [36]. Facebook introduced the Facebook live function in April 2016, to keep track on the growing competitiveness of other platforms in the field of image and 
video [39]. YouTube channels of - mostly young - people, posting Vlogs about their everyday lives on the street in their neighbourhoods, provide opportunities to create new public figures in neighbourhoods. Furthermore, the development of video screens in public spaces is remarkable in this account. Veenstra [40] shows the potential impact of using interactive displays in public spaces. Experiments of showing urban dashboards on public screens to create city services are promising in this regard.

\subsection{Trend 4: Gamification and serious gaming}

Today, an increasing number of games are designed for serious purposes [41]. There is an exponential growth in digital games in popular culture [42]. Serious games can be played in a wide variety of fields, often using simulations of real-world events, adopted with gaming characteristics. It is therefore providing players of a game with tools to gain more insights in fields of problems, mutual positions or even development tools $[41,43,44]$. Gaming for the purpose of training, strategizing and learning is already widely accepted. A step further would be to see if gaming could even be working predictively and for policy-making. This is still on debate within scientific literature [41].

We saw that one of the important characteristics of urban media is time and place independency, given by the use of smartphones. The same trend is recognizable within the development of serious gaming for city development. These forms of urban media are the topic of various studies that aim to show the possibilities for enhancing citizen participation in area development.

\subsection{Trend 5: Virtual and Augmented Reality}

A variety of applications using both virtual and augmented reality is currently being developed. Several studies show the potential of using those techniques in the process of urban planning [45]. The use of virtual worlds on mobile applications also proofed to be a suitable tool for stimulation citizen to participate in the process of urban planning [46]. Studies show a growing and wide variety of possibilities for the use of Virtual Reality Geographical Information Systems (VRGIS) and Augmented Reality Geographical Information Systems. All creating possibilities for smarter urban planning and citizen involvement in that process [42]. In 2016, the augmented reality game Pokémon Go showed an enormous impact on the use of public areas. This even led to prohibiting people to enter certain public areas for searching Pokémon [31, 32].

\subsection{Trend 6: New actors in area development}

With the increase of smart city techniques, also new actors present themselves in the field of urban planning. Large scale area development, such as proposed by Google affiliated company Sidewalk labs in Toronto, are examples of such. Companies such as Cisco, IBM or Siemens that originate in sectors like ICT, Social Media or hardware development, now develop strategies for urban planning and city planning. Companies that do not have any rooted experience in these fields. Some experts in the field of urban planning consider this lack of historical awareness and knowledge on the process of 
urban planning, a dangerous development [10]. Especially since urban planning is considered a complex process [46]. Many of these actors tend to approach a city and urban development in a more rational way, almost comparable to the traditional approaches of urban planning that dictated the planning discourse in the first half of the twentieth century [11]. This has already led to criticism of the development of smart cities for being too technocratic and top-down in orientation. This could result in a structural neglecting of citizens interests and ignoring their needs [1, 2, 47-49]. Reactions of the companies in describing strategies towards more citizen-focused strategies, do not provide a more citizen-focused form of urban planning in smart cities [49].

\section{Analysis of urban media for area development}

We carefully analyzed the aforementioned trends in relation to the defined aspects of successful urban development in existing neighbourhoods. This analysis took place by developing a confrontation matrix where the trends were assessed on the found aspects of area development. The analysis resulted in either a potential positive effect, a potential negative effect, or no expected effect at all. While the analysis is not yet validated with large scale empirical data we encourage further research. The analysis is displayed in Table 2 and 3 and shows an overview of expected value based on theoretical and expert assumptions that were found in the research.

Table 2. Analysis trend 1-3.

\begin{tabular}{|c|c|c|c|}
\hline & Platform-society & Citizen generated data & Image and video \\
\hline & Positive effect expected & & Positive effect expected \\
\hline $\begin{array}{l}\text { Own par- } \\
\text { ticipation }\end{array}$ & $\begin{array}{l}\text { Platforms lower the } \\
\text { barriers for citizens to } \\
\text { participate }\end{array}$ & $\begin{array}{l}\text { No great influence ex- } \\
\text { pected }\end{array}$ & $\begin{array}{l}\text { New target groups can be } \\
\text { reached through video plat- } \\
\text { forms. These are low barrier } \\
\text { options to participate. }\end{array}$ \\
\hline $\begin{array}{l}\text { Clear role } \\
\text { of govern- } \\
\text { ment }\end{array}$ & $\begin{array}{l}\text { No great influence ex- } \\
\text { pected }\end{array}$ & $\begin{array}{l}\text { Negative effect expected } \\
\text { Ethical dilemmas make } \\
\text { the extensive use of } \\
\text { data risky }\end{array}$ & No great influence expected \\
\hline & $\begin{array}{l}\text { Negative effect ex- } \\
\text { pected }\end{array}$ & Positive effect expected & Positive effect expected \\
\hline Diversity & $\begin{array}{l}\text { Because of the effect of } \\
\text { filter bubbles on plat- } \\
\text { forms, groups tend to } \\
\text { develop in a homoge- } \\
\text { nous way. }\end{array}$ & $\begin{array}{l}\text { When using data ana- } \\
\text { lytics, data and opin- } \\
\text { ions of every target } \\
\text { group can be taken into } \\
\text { account. }\end{array}$ & $\begin{array}{l}\text { New target groups can be } \\
\text { reached through video plat- } \\
\text { forms. }\end{array}$ \\
\hline & $\begin{array}{l}\text { Negative effect ex- } \\
\text { pected }\end{array}$ & Positive effect expected & Positive effect expected \\
\hline $\begin{array}{l}\text { by minor- } \\
\text { ities }\end{array}$ & $\begin{array}{l}\text { Because of the homoge- } \\
\text { nous development, mi- } \\
\text { norities can be in dan- } \\
\text { ger of not being heard. }\end{array}$ & $\begin{array}{l}\text { When using data analyt- } \\
\text { ics, data and opinions of } \\
\text { every target group can be } \\
\text { taken into account. }\end{array}$ & $\begin{array}{l}\text { New target groups can be } \\
\text { reached through video plat- } \\
\text { forms. }\end{array}$ \\
\hline
\end{tabular}


Table 3. Analysis trend 1-3 (continued)

\begin{tabular}{|c|c|c|c|}
\hline & Platform-society & Citizen generated data & Image and video \\
\hline $\begin{array}{l}\text { Widely set } \\
\text { goals by gov- } \\
\text { ernment }\end{array}$ & $\begin{array}{l}\text { No great influence ex- } \\
\text { pected }\end{array}$ & $\begin{array}{l}\text { No great influence ex- } \\
\text { pected }\end{array}$ & $\begin{array}{l}\text { No great influence ex- } \\
\text { pected }\end{array}$ \\
\hline $\begin{array}{l}\text { Room for ex- } \\
\text { perimentation }\end{array}$ & $\begin{array}{l}\text { Positive effect expected } \\
\text { Platforms provide an op- } \\
\text { portunity for exchanging } \\
\text { ideas and improve exper- } \\
\text { imental development. }\end{array}$ & $\begin{array}{l}\text { No great influence ex- } \\
\text { pected }\end{array}$ & $\begin{array}{l}\text { No great influence ex- } \\
\text { pected }\end{array}$ \\
\hline $\begin{array}{l}\text { Dynamics in } \\
\text { society }\end{array}$ & $\begin{array}{l}\text { Positive effect expected } \\
\text { Platforms provide oppor- } \\
\text { tunities to exchange } \\
\text { ideas and benefit from } \\
\text { energy in society. }\end{array}$ & $\begin{array}{l}\text { Positive effect expected } \\
\text { Predictive analysis of } \\
\text { data, can identify the } \\
\text { dynamics of society. }\end{array}$ & $\begin{array}{l}\text { No great influence ex- } \\
\text { pected. }\end{array}$ \\
\hline
\end{tabular}

Table 4. Analysis trend 4-6

\begin{tabular}{|c|c|c|c|}
\hline & Serious gaming & VR/AR & New actors in area development \\
\hline & $\begin{array}{l}\text { Positive effect } \\
\text { expected }\end{array}$ & $\begin{array}{l}\text { No great } \\
\text { influence }\end{array}$ & Negative effect expected \\
\hline $\begin{array}{l}\text { Own par- } \\
\text { ticipation }\end{array}$ & $\begin{array}{l}\text { Serious gaming } \\
\text { stimulates par- } \\
\text { ticipation of oth- } \\
\text { erwise less -in- } \\
\text { terested target } \\
\text { group }\end{array}$ & expected. & $\begin{array}{l}\text { New actors lack insights and root- } \\
\text { ing in urban planning methods. } \\
\text { They can have a poorly developed } \\
\text { historical awareness. Often city } \\
\text { development is approached in a ra- } \\
\text { tionalised, technocratic manner. } \\
\text { This does not support clear and } \\
\text { 'free' citizen participation. }\end{array}$ \\
\hline $\begin{array}{l}\text { Clear role } \\
\text { of govern- } \\
\text { ment }\end{array}$ & $\begin{array}{l}\text { Positive effect } \\
\text { expected } \\
\text { Role playing ele- } \\
\text { ments show } \\
\text { clear division of } \\
\text { roles. }\end{array}$ & $\begin{array}{l}\text { No great in- } \\
\text { fluence ex- } \\
\text { pected. }\end{array}$ & $\begin{array}{l}\text { Negative effect expected } \\
\text { In some cases, new actors make } \\
\text { contracts with local governments. } \\
\text { This could harm the needed trans- } \\
\text { parency and clear choice of gov- } \\
\text { ernmental role. }\end{array}$ \\
\hline & $\begin{array}{l}\text { Positive effect } \\
\text { expected }\end{array}$ & $\begin{array}{l}\text { No great } \\
\text { influence }\end{array}$ & Negative effect expected \\
\hline Diversity & $\begin{array}{l}\text { Serious games } \\
\text { can provide in- } \\
\text { sights in oppos- } \\
\text { ing angles and } \\
\text { show that target } \\
\text { groups perhaps } \\
\text { are forgotten. }\end{array}$ & expected. & $\begin{array}{l}\text { The of lack insights and rooting in } \\
\text { urban planning methods does not } \\
\text { benefit the 'inefficient' use of di- } \\
\text { verse public. }\end{array}$ \\
\hline
\end{tabular}


Table 5. Analysis trend 4-6 (continued)

\begin{tabular}{|c|c|c|c|}
\hline & Serious gaming & VR/AR & New actors in area dev. \\
\hline & $\begin{array}{l}\text { Positive effect } \\
\text { expected }\end{array}$ & $\begin{array}{l}\text { Positive effect ex- } \\
\text { pected }\end{array}$ & Negative effect expected \\
\hline $\begin{array}{l}\text { Influence } \\
\text { by minori- } \\
\text { ties }\end{array}$ & $\begin{array}{l}\text { Serious games } \\
\text { provide possi- } \\
\text { bilities to gener- } \\
\text { ate insights in } \\
\text { opposing an- } \\
\text { gles. Also it lifts } \\
\text { support for op- } \\
\text { posing views. }\end{array}$ & $\begin{array}{l}\text { VR and AR gener- } \\
\text { ate possibilities to } \\
\text { show area develop- } \\
\text { ment through the } \\
\text { eyes of someone } \\
\text { else. Therefor also } \\
\text { generating support } \\
\text { for minorities, like } \\
\text { disabled people. }\end{array}$ & $\begin{array}{l}\text { The lack of insights and } \\
\text { rooting in urban planning } \\
\text { methods does not benefit } \\
\text { the 'inefficient' use of di- } \\
\text { verse public. This could } \\
\text { be dangerous for the need } \\
\text { of involving minorities. }\end{array}$ \\
\hline \multirow{2}{*}{$\begin{array}{l}\text { Widely set } \\
\text { goals by } \\
\text { govern- } \\
\text { ment }\end{array}$} & $\begin{array}{l}\text { No great influ- } \\
\text { ence expected. }\end{array}$ & $\begin{array}{l}\text { No great influence } \\
\text { expected. }\end{array}$ & $\begin{array}{l}\text { No great influence ex- } \\
\text { pected. }\end{array}$ \\
\hline & $\begin{array}{l}\text { Positive effect } \\
\text { expected }\end{array}$ & $\begin{array}{l}\text { Positive effect ex- } \\
\text { pected }\end{array}$ & Negative effect expected \\
\hline $\begin{array}{l}\text { Room for } \\
\text { experimen- } \\
\text { tation }\end{array}$ & $\begin{array}{l}\text { Serious games } \\
\text { provide possi- } \\
\text { bilities for ex- } \\
\text { periments and } \\
\text { test them in } \\
\text { simulated situa- } \\
\text { tions. }\end{array}$ & $\begin{array}{l}\text { VR and AR gener- } \\
\text { ate possibilities for } \\
\text { showing the effect } \\
\text { of experiments and } \\
\text { adjust them end- } \\
\text { lessly. }\end{array}$ & $\begin{array}{l}\text { The lack of insights and } \\
\text { rooting in urban planning } \\
\text { methods does not always } \\
\text { fit to an experimental ap- } \\
\text { proach to urban planning. }\end{array}$ \\
\hline & $\begin{array}{l}\text { Positive effect } \\
\text { expected }\end{array}$ & $\begin{array}{l}\text { Positive effect ex- } \\
\text { pected }\end{array}$ & Positive effect expected \\
\hline $\begin{array}{l}\text { Dynamics } \\
\text { in society }\end{array}$ & $\begin{array}{l}\text { Serious games } \\
\text { thrive on enthu- } \\
\text { siasm. This } \\
\text { functions better } \\
\text { when acting on } \\
\text { the dynamics of } \\
\text { society. }\end{array}$ & $\begin{array}{l}\text { VR and AR can } \\
\text { generate enthusi- } \\
\text { asm by creating } \\
\text { possibilities to envi- } \\
\text { sion endless num- } \\
\text { ber of possible fu- } \\
\text { ture developments } \\
\text { in neighbourhoods. }\end{array}$ & $\begin{array}{l}\text { New actors often have a } \\
\text { good antenna for finding } \\
\text { the dynamics in society. } \\
\text { This could benefit initia- } \\
\text { tives for neighbourhood } \\
\text { development that thrives } \\
\text { on these dynamics. }\end{array}$ \\
\hline
\end{tabular}

\section{Discussion}

It can be concluded that the six main trends we defined regarding the development of urban media, each show their own impact on citizen participation in urban planning. Some of the identified trends could even have a mutually amplifying effect, which makes the contribution of urban media even more significant to urban planning. The relatively new actors in urban planning that are rooted in the world of ICTs, gain lots of criticism in their technocratic role in the development of smart cities. Since they do not have a background in urban planning these new actors may have a negative impact on citizen involvement in urban planning. 
Various limitations of our research have to be mentioned here. First, we focused completely on urban media trends that were identified from literature and experts. This means that we did not explore or revisited the body of knowledge regarding all kinds of earlier city participation technologies such as online forums, open data initiatives, web planning tools, cloud services and so on. A second limitation, raised here, is that our interviewees, that we considered as experts in this field, were exclusively from the Netherlands. This potentially limits the generalizability of the findings for other countries where the trends could not be that strong as in a country with the highest level of internet access. Urban media shows some remarkable opportunities for city planning in local neighbourhoods but has to be applied with care. The analysis in this article showed that some functions are better supported than others. And solely the existence of urban media does not solve the lack of interest in participation. Yet we have to find those specific configurations and strategies that enhance participation, based on hard work of people and creating valuable relationships. In that sense, urban media is maybe an old wine in a new barrel.

\section{References}

1. Cardullo, P., Kitchin, R.: Being a "citizen" in the smart city: Up and down the scaffold of smart citizen participation (2017).

2. Lange, M. de, Waal, M. de: Owning the city: New media and citizen engagement in urban design. First on Monday. 18, (2013).

3. Angelidou, M.: The Role of Smart City Characteristics in the Plans of Fifteen Cities. J. Urban Technol. 24, 3-28 (2017).

4. Effing, R., Groot, B.P.: Social smart city: Introducing digital and social strategies for participatory governance in smart cities. In: Lecture Notes in Computer Science (2016).

5. Foth, M., Tomitsch, M., Forlano, L., Haeusler, M.H., Satchell, C.: Citizens breaking out of filter bubbles. In: Proceedings of the 5th ACM International Symposium on Pervasive Displays - PerDis '16 (2016).

6. Foth, M., Tomitsch, M., Satchell, C., Haeusler, M.H.: From Users to Citizens. In: Proceedings of the Annual Meeting of the Australian Special Interest Group for Computer Human Interaction on - OzCHI '15 (2015).

7. Ahlers, D., Driscoll, P., Löfström, E., Krogstie, J., Wyckmans, A.: Understanding Smart Cities As Social Machines. In: 25th International Conference Companion on www. pp. 759764, Republic and Canton of Geneva, Switzerland (2016).

8. Waal, M. de: De Stad als Interface Digitale Media en Stedelijke Openbaarheid, http://hdl.handle.net/11370/effb9976-60cb-4c4f-8c52-c31c1bdf87ee, (2012).

9. Castells, M.: The Rise of the Network Society. Wiley-Blackwell, Oxford (1996).

10. Hajer, M., Dassen, T.: Smart About Cities. Visualising the Challenge for 21st century urbanism. NAI010, Rotterdam (2014).

11. Alexander, E.R.: After rationality. Society. 26, 15-19 (1988).

12. Cammen, H. van der, Klerk, L. de: Ruimtelijke ordening van grachtengordel tot Vinex-wijk. Het Spectrum, Utrecht (2003).

13. Brooks, M.P.: Planning Theory for Practitioners. American Planning Association, Chicago (2002).

14. Jacobs, J.: The Death and Life of Great American Cities. Random House, New York (1961). 
15. Davidoff, P.: Advocacy and Pluralism in Planning. In: Readings in Planning Theory: Fourth Edition (2016).

16. Arnstein, S.R.: A Ladder Of Citizen Participation. J. Am. Inst. Plann. 35, 216-224 (1969).

17. Grönlund, Å.: ICT Is Not Participation Is Not Democracy - eParticipation Development Models Revisited. In: ePart 2009. pp. 12-23 (2009).

18. Pröpper, I.: De aanpak van interactief beleid: elke situatie is anders. Coutinho, Bussum (2009).

19. Lodigiani, A.: E-Planning: The Digital Toolbox in Participatory Urban Planning. In: Contin, A., Paolini, P., and Salerno, R. (eds.) Innovative Technologies in Urban Mapping: Built Space and Mental Space. pp. 135-144. Springer International Publishing, Cham (2014).

20. Hajer, M.: De Energieke Samenleving. Planbureau voor de Leefomgeving, Den Haag (2011).

21. Lindblom, C.E.: The Science of Muddling Through. Public Adm. Rev. 19, 79-88 (1959).

22. Wellman, B., Quan-Haase, A., Boase, J., Chen, W., Hampton, K., Díaz, I., Miyata, K.: The Social Affordances of the Internet for Networked Individualism. J. Comput. Commun. 8, 0 0 (2006).

23. Brafman, O., Beckstrom, R.: The Starfish and the Spider: The Unstoppable Power of Leaderless Organizations. Penguin Putnam Inc., New York (2006).

24. Townsend, A.: Smart cities. Big data, civic hackers, and the quest for a new Utopia. W.W. Norton \& Company, New York/London (2013).

25. Meijer, A.: Bestuur in de datapolis: Slimme stad, blije burger? Boombestuurskunde, Den Haag (2015).

26. Caragliu, A., Del Bo, C., Nijkamp, P.: Smart Cities in Europe. J. Urban Technol. 18, 65-82 (2011).

27. Neirotti, P., De Marco, A., Cagliano, A.C., Mangano, G., Scorrano, F.: Current trends in Smart City initiatives: Some stylised facts. Cities. 38, 25-36 (2014).

28. Granier, B., Kudo, H.: How are citizens involved in smart cities? Analysing citizen participation in Japanese "Smart Communities." Inf. Polity. 21, 61-76 (2016).

29. Denters, B., Tonkens, E., Verhoeven, I., Bakker, J.: Burgers maken hun buurt. , Den Haag (2013).

30. Ellison, N.B., Steinfield, C., Lampe, C.: The Benefits of Facebook "Friends:" Social Capital and College Students' Use of Online Social Network Sites. J. Comput. Commun. 12, 11431168 (2007).

31. Den Haag Marketing: De beste Pokémon Go-hotspots In Kijkduin, Scheveningen en de Haagse binnenstad, https://denhaag.com/nl/pokemon.

32. Gemeente Den Haag: Pokémonspelers: houd Kijkduin schoon en leefbaar, https://www.denhaag.nl/home/bewoners/stadsdelen-enwijken/loosduinen/to/Pokemonspelers-houd-Kijkduin-schoon-en-leefbaar.htm.

33. Dijck, J. van, Poell, T., Waal, M. de: De platformsamenleving. Amsterdam University Press, Amsterdam (2016).

34. Dijck, J. van: The Culture of Connectivity: A Critical History of Social Media. Oxford University Press, Oxford (2013).

35. Helmond, A.: The Platformization of the Web: Making Web Data Platform Ready. Soc. Media + Soc. 1, 2056305115603080 (2015).

36. Kaplan, A.M., Haenlein, M.: Users of the world, unite! The challenges and opportunities of Social Media. Bus. Horiz. 59-68 (2010).

37. Wei, L., Yan, Y.: Knowledge Production and Political Participation: Reconsidering the Knowledge Gap Theory in the Web 2.0 Environment. In: ICIME 2010 (2010).

38. Comscore: Global Digital Future in Focus. 2018 international edition. (2018). 
39. Zuckerberg, M.: Facebook Mark Zuckerberg posts. https://www.facebook.com/zuck/posts/10102764095821611.

40. Veenstra, M.: Verbonden en verbindend. De openbare ruimte in de smart city., Enschede (2016).

41. Tan, E.: The Evolution of City Gaming. In: Portugali, J. and Stolk, E. (eds.) Complexity, Cognition, Urban Planning and Design. pp. 271-292. Springer International Publishing, Cham (2016).

42. Kamel Boulos, M.N., Lu, Z., Guerrero, P., Jennett, C., Steed, A.: From urban planning and emergency training to Pokémon Go: Int. J. Health Geogr. 16, 7 (2017).

43. Abt, C.C.: Serious Games. Viking Press, New York (1970).

44. Schouten, B., Ferri, G., de Lange, M., Millenaar, K.: Games as Strong Concepts for CityMaking. In: Nijholt, A. (ed.) Playable Cities: The City as a Digital Playground. pp. 23-45. Springer Singapore, Singapore (2017).

45. Zhang, S., Moore, A.B.: The Usability of Online Geographic Virtual Reality for Urban Planning. In: Isikdag, U. (ed.) Innovations in 3D Geo-Information Sciences. pp. 225-242. Springer International Publishing, Cham (2014).

46. Jutraz, A., Zupancic, T.: Virtual Worlds as Support Tools for Public Engagement in Urban Design. In: Geertman e.a. (eds.) Planning Support Systems and Smart Cities. pp. 391-408. Springer International Publishing, Cham (2015).

47. Vanolo, A.: Is there anybody out there? The place and role of citizens in tomorrow's smart cities. Futures. 82, 26-36 (2016).

48. Shelton, T., Zook, M., Wiig, A.: The "actually existing smart city." Cambridge J. Reg. Econ. Soc. 8, 13-25 (2015).

49. Kitchin, R.: Making sense of smart cities: addressing present shortcomings. Cambridge J. Reg. Econ. Soc. 8, 131-136 (2015). 